\title{
ANALISIS DAN PERANCANGAN SISTEM INFORMASI LAYANAN PELANGGAN PDAM TIRTA MAYANG KOTA JAMBI BERBASIS SMS
}

\author{
$\underline{\text { Ikhsanul Poetra }^{1}, \text { Herry Mulyono }}{ }^{2}$ \\ Program Studi Magister Sistem Informasi, STIKOM Dinamika Bangsa, Jambi \\ Jl. Jendral Sudirman, Kec. The Hok, (0741) 35095 \\ Email : poetraikhsanul@gmail.com, herrymulyono@stikom-db.ac.id ${ }^{2}$
}

\begin{abstract}
Abstrak
Kepuasan pelanggan terhadap pelayanan PDAM Tirta Mayang Kota Jambi berkaitan dengan tingkat kualitas pelayanan yang diberikan. Penggunaan TI dapat membantu meningkatkan kualitas pelayanan di PDAM Tirta Mayang Kota Jambi dan dipandang sebagai aset strategis yang turut menentukan strategi bisnis PDAM Tirta Mayang Kota Jambi. Penelitian ini dilaksanakan dengan tujuan untuk merancang sistem informasi ITSM pada PDAM Tirta Mayang Kota Jambi. Metode pengumpulan data yang digunakan yaitu metode wawancara, observasi dan dokumentasi, selanjutnya data dan informasi yang diperoleh dianalisis yang menghasilkan sebuah analisa kondisi sistem yang sedang berjalan. Adapun sistem yang dirancang berupa protitipe yang rancangannya mengikuti setiap tahapan proses ITIL versi 3 area service operation, yaitu: proses event management, incident management (incident identification, incident logging, incident categorization, incident prioritization, initial diagnosis, incident escalation, investigation and diagnosis, resolution and recovery, incident closure), request fulfillment, problem management, dan access management. Hasil penelitian ini berupa sebuah rancangan sistem informasi ITSM pada PDAM Tirta Mayang Kota Jambi yang dirancang berdasarkan framework ITIL versi 3 area service operation.
\end{abstract}

Kata kunci : SIM Layanan Pelanggan, ITSM, ITIL versi 3, Service Operation.

\begin{abstract}
Customer satisfaction towards PDAM Tirta Mayang Jambi services is associated with the level of service quality of service provided. The use of IT can help to improve the quality of services at PDAM Tirta Mayang Jambi and is viewed as a strategic asset that helps to determine business strategies of PDAM Tirta Mayang Jambi. This research was conducted with the aim to design information system of PDAM Tirta Mayang ITSM Jambi. Data collection method used is through interview, observation and documentation, as the data and information obtained were analyzed which resulted in an analysis of the condition of the running system. The system is designed in the form of protitipe which its design follows each stage of ITIL version 3 area service operation, namely: the process of event management, incident management (incident identification, incident logging, incident categorization, incident prioritization, initial diagnosis, incident escalation, investigation and diagnosis, resolution and recovery, incident closure), request fulfillment, problem management, and access management. The results of this study is in the form of an information system design ITSM on PDAM Tirta Mayang Jambi City designed based framework ITIL version 3 service operation area.
\end{abstract}

Keywords : MIS Customer Service, ITSM, ITIL version 3, Service Operation.

(C) 2019 Jurnal Magister Sistem Informasi. 


\section{Pendahuluan}

1) Air bersih merupakan salah satu kebutuhan pokok manusia yang dibutuhkan secara berkelanjutan. Penggunaan air bersih sangat penting untuk konsumsi rumah tangga, kebutuhan industri dan tempat umum. Karena pentingnya kebutuhan akan air bersih, maka adalah hal yang wajar jika sektor air bersih mendapatkan prioritas penanganan utama karena menyangkut kehidupan orang banyak.

2) Untuk memenuhi kebutuhan akan air bersih di Kota Jambi dilakukan melalui dua cara, yaitu melalui jaringan air nonperpipaan dan jaringan air perpipaan. Dalam hal ini Perusahaan Daerah Air Minum Tirta Mayang Kota Jambi (selanjutnya disebut PDAM Tirta Mayang Kota Jambi) merupakan Badan Usaha Milik Daerah yang bertugas sebagai pengelola pendistribusian air bersih untuk kebutuhan masyarakat di Kota Jambi.

3) Kepuasan pelanggan terhadap pelayanan PDAM Tirta Mayang Kota Jambi berkaitan dengan tingkat kualitas pelayanan yang diberikan. Pemenuhan kebutuhan tersebut erat kaitannya dengan kualitas pelayanan yang dapat diukur dengan melihat keluhan dan umpan balik dari masyarakat, diantaranya kualitas air, distribusi dan pelayanan.

4) Penggunaan teknologi informasi yang semakin berkembang saat ini akan sangat membantu PDAM Tirta Mayang Kota Jambi untuk meningkatkan kualitas pelayanan kepada pelanggan. Oleh karena itu, pemanfaatan teknologi informasi pada bidang layanan pelanggan di PDAM Tirta Mayang Kota Jambi tentunya juga menjadi suatu kebutuhan, dan tidak hanya ditempatkan pada posisi pendukung saja seperti untuk komputasi data dan otomatisasi proses, namun juga dipandang sebagai aset strategis yang turut menentukan strategi bisnis PDAM Tirta Mayang Kota Jambi.

5) Terkait dengan kebutuhan yang mendasar dari PDAM Tirta Mayang Kota Jambi terhadap peningkatan kualitas pelayanan kepada pelanggan, dan perkembangan teknologi informasi, maka penulis tertarik untuk melakukan penelitian.

\section{Tinjauan Pustaka}

Penelitian ini dilakukan tidak terlepas dari hasil penelitian-penelitian terdahulu yang pernah dilakukan sebagai bahan perbandingan dan kajian. Adapun hasil-hasil penelitian yang dijadikan perbandingan dalam penelitian ini tidak terlepas dari judul penelitian.

Adapun penelitian yang relevan dengan penelitian yang penulis lakukan ini adalah penelitian yang dilakukan oleh:

1. Nurfaizah, dkk (2015) pada jurnal penelitiannya yang berjudul "Rancangan

Information Technology Service Management Menggunakan Information Technology Infrastrukture Library (Studi Kasus: STMIK AMIKOM Purwokerto)”.

Dalam penelitiannya, Nurfaizah, dkk mengungkapkan bahwa tujuan dari penelitiannya adalah:

a. Mengetahui kondisi penerapan manajemen penggunaan teknologi informasi dan sistem informasi.

b. Mengidentifikasi permasalahan pada proses manajemen dukungan layanan

c. Mengimplementasikan framework ITIL pada penerapan sistem informasi, khususnya dalam merancang IT Service Management. 
Metode pengumpulan data yang digunakan oleh Nurfaizah, dkk adalah studi literatur dan metode lapangan (wawancara dan kuesioner), sedangkan metode analisis data yang digunakan adalah menggunakan alur framework IT Infrastructure Library domain service support dan service delivery.

Hasil penelitian yang diperoleh adalah ITSM menghasilkan perancangan pada masingmasing prosesnya dari 2 domain pembangun ITSM yaitu domain service support dan service delivery.

Persamaan penelitian yang dilakukan oleh Nurfaizah, dkk dengan penelitian yang penulis lakukan adalah:

a. Merancang IT Service Management dengan menggunakan framework ITIL

b. Proses kerja yang digunakan untuk menganalisa dan merancang memiliki tahapan yang sama yaitu incident management, request fulfillment, problem management, service desk fungction.

Perbedaan penelitian yang dilakukan oleh Nurfaizah, dkk dengan penelitian yang penulis lakukan adalah:

a. Domain penelitian yang digunakan oleh Nurfaizah, dkk adalah domain service support dan service delivery sedangkan penelitian yang penulis gunakan menggunakan domain service operation pada framework ITIL yang merupakan pengembangan dari domain service support dan service delivery.

b. Penelitian yang dilakukan Nurfaizah, dkk, tidak menjelaskan tahapan event management, access management, dan operational activities, yang merupakan bagian dari tahapan framework ITIL.

c. Penelitian yang dilakukan oleh Nurfaizah, dkk hanya memberikan rekomendasi dari setiap tahapan dalam framework ITIL, namun tidak sampai pada tahap perancangan terhadap sistem.

d. Framework ITIL yang digunakan oleh Nurfaizah, dkk mengelola layanan sebagai sekumpulan proses dan fungsi sementara penelitian yang penulis gunakan dalam framework ITIL mengelola layanan sebagai sebagai sebuah lifecycle/daur hidup.

2. Ramadhani (2014) pada jurnal penelitiannya yang berjudul "Penerapan Information Technology Infrastructure Library Framework pada Sistem Manajemen Service Desk (Studi Kasus: PT. Firstmedia, Tbk)".

Dalam penelitiannya, Ramadhani mengungkapkan bahwa dalam meningkatkan pelayanan TI di PT. Firstmedia, Tbk guna menunjang visi PT. Firstmedia, Tbk menjadi perusahaan yang mengedepankan kualitas dan layanan maka salah satu upaya untuk peningkatan layanan TI ini yaitu dengan membangun sebuah pusat pengaduan dan layanan TI sebagai titik kontak tunggal yang menjembatani antara karyawan dengan penyedia layanan.

Metode pengumpulan data yang digunakan oleh Ramadhani adalah observasi, wawancara dan studi pustaka, sedangkan tahapan metode pengembangan sistem yang dilakukan adalah dengan menganalisis kebutuhan software, desain sistem, code generation, testing, dan support.

Hasil penelitian yang telah dilakukan oleh Ramadhani dalam penelitiannya adalah dengan menggunakan konsep framework ITIL aplikasi IT Helpdesk yang diusulkan dapat mengurangi masalah human error dalam proses pencatatan data helpesk dan 
dapat menghasilkan laporan-laporan yang diharapkan dapat membantu proses pengambilan keputusan internal pada divisi IT dan juga perusahaan.

Persamaan penelitian yang dilakukan oleh Ramadhani dengan penelitian yang penulis lakukan adalah merancang IT Service Management dengan menggunakan framework ITIL.

Perbedaan penelitian yang dilakukan oleh Ramadhani dengan penelitian yang penulis lakukan adalah penelitian yang dilakukan oleh Ramadhani menggunakan area pada framework ITIL yaitu service operation, service transition dan continual service improvement yang merupakan bagian dari daur hidup pada framework ITIL.

3. Sari, dkk. (2010) pada jurnal penelitiannya yang berjudul "Sistem Manajemen Layanan Pelanggan Pada Della Skin Care Palembang Berbasis Android".

Dalam penelitiannya, Sari, dkk. mengungkapkan bahwa study ini dilakukan untuk mengembangkan sistem manajemen hubungan pelanggan yang membantu meningkatkan layanan pelanggan.

Metode yang digunakan dalam pengumpulan data menggunakan metode observasi, wawancara dan studi pustaka. Metodologi pengembangan sistem yang digunakan adalah Waterfall yang memiliki beberapa tahapan yaitu. Dalam pengembangan sistem, bahasa pemrograman yang digunakan adalah Java, Java untuk membangun aplikasi Android, basis data yang digunakan adalah MySQL.

Hasil penelitian yang telah dilakukan oleh Sari, dkk. dalam penelitiannya adalah aplikasi sistem manajemen layanan pelanggan pada della skin care berbasis Android berdasarkan kerangka PIECES untuk mengkategorikan permasalahan yang ditemukan sesuai dengan kebutuhan masyarakat.

Persamaan penelitian yang dilakukan oleh Sari, dkk. dengan penelitian yang penulis lakukan adalah merancang sistem manajemen layanan pelanggan yang membantu meningkatkan layanan pelanggan.

Perbedaan penelitian yang dilakukan oleh Sari, dkk. dengan penelitian yang penulis lakukan adalah penelitian yang dilakukan oleh Sari, dkk. menggunakan Android sebagai interface terhadap user, dan telah diimplementasikan Della Skin Care Palembang.

\section{Metodologi}

Adapun alur penelitian yang akan dilakukan dalam penelitian yaitu identifikasi masalah, studi literatur, pengumpulan data, analisis data, perancangan aplikasi, dan pembuatan laporan, seperti yang terlihat pada gambar 3.1 berikut: 


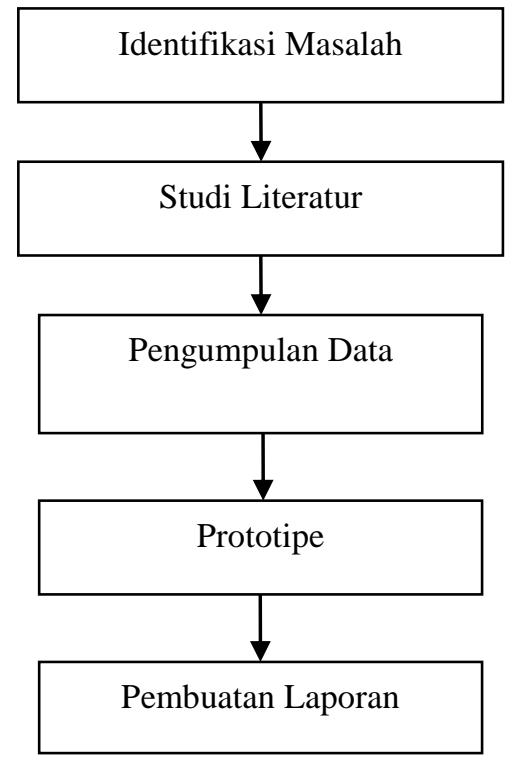

Gambar 3.1 Alur Penelitian

Berdasarkan alur penelitian yang telah digambarkan pada gambar 3.1 di atas, maka dapat diuraikan pembahasan masing-masing tahap dalam penelitian adalah sebagai berikut: 1. Identifikasi Masalah

Mengidentifikasi masalah merupakan langkah awal yang penulis lakukan. Hal ini bertujuan untuk menentukan permasalahan apa yang akan penulis angkat dalam penelitian ini. Tahap identifikasi masalah dimulai dengan merumuskan masalah yang dibatasi oleh batasan masalah dan kemudian dilanjutkan dengan penentuan tujuan penelitian serta manfaat penelitian yang akan diperoleh.

2. Studi Literatur

Pada tahapan ini, penulis mengumpulkan teori-teori yang digunakan untuk menjadi dasar penelitian dengan mempelajari buku-buku referensi, artikel-artikel dan jurnal ilmiah, serta melakukan tinjauan pustaka dengan mempelajari penelitian yang relevan yang pernah dilakukan sebagai bahan perbandingan dan kajian.

3. Pengumpulan Data

a. Pengumpulan Data

Pengumpulan data merupakan salah satu tahapan penting dalam suatu proses penelitian. Dengan mendapatkan data yang tepat, maka proses penelitian dapat berlangsung tanpa hambatan sehingga penulis mendapatkan jawaban dari perumusan masalah yang telah ditetapkan sebelumnya.

Pada tahap ini penulis mulai bekerja dengan mendefinisikan dan mengumpulkan semua data dan informasi sebagai bahan pendukung yang sangat berguna bagi penulis.

Objek utama dari penelitian ini adalah pada bagian Pengaduan dan Pelayanan Gangguan Pelanggan PDAM Tirta Mayang Kota Jambi. Adapun teknik pengumpulan data yang penulis lakukan dalam penelitian ini adalah sebagai berikut:

a) Wawancara

Penulis melakukan pengumpulan data dengan cara tanya jawab kepada pihak PDAM Tirta Mayang Kota Jambi yang dianggap dapat memberikan informasi 
yang tepat terkait dengan penelitian, yaitu Kepala Bagian SDM dan Umum, Kepala Bagian PKA dan LITBANG, Kepala Seksi PPG, dan Operator.

b) Observasi

Observasi dilakukan dengan cara pengamatan langsung suatu kegiatan yang sedang dilakukan pada bagian Pengaduan dan Pelayanan Gangguan Pelanggan PDAM Tirta Mayang Kota Jambi. Pada metode ini penulis mangamati secara langsung proses pengaduan dan pelayanan gangguan pelanggan PDAM Tirta Mayang Kota Jambi.

c) Dokumentasi

Dokumentasi dilakukan dengan cara mengumpulkan data dengan mempelajari catatan atau dokumen pada bagian Pengaduan dan Pelayanan Gangguan Pelanggan PDAM Tirta Mayang Kota Jambi yang berhubungan dengan masalah yang diteliti. Dokumen ini akan dapat memberikan gambaran mengenai keadaan yang diteliti.

b. Analisis Data

Data dan informasi yang berasal dari hasil pengumpulan data kemudian dianalisis yang menghasilkan sebuah analisa kondisi sistem yang sedang berjalan saat ini. Selanjutnya mencari solusi pemecahan masalah dari permasalahan-permasalahan yang ditemui pada bagian Pengaduan dan Pelayanan Gangguan Pelanggan PDAM Tirta Mayang Kota Jambi. Usulan solusi pemecahan masalah yang diberikan selanjutnya dilakukan analisis kebutuhan terhadap sistem yang akan dirancang beserta databasenya.

4. Prototipe

Pada tahap ini penulis membuat prototipe sistem berdasarkan hasil analisis yang telah dilakukan. Adapun prototipe yang dibangun pada penelitian ini memiliki proses utama yaitu:

a. Proses Incident Management

Masukan ke dalam proses ini berupa laporan keluhan pengguna layanan melalui sms ataupun pelanggan yang datang langsung pada bagian Pengaduan dan Pelayanan Gangguan Pelanggan PDAM Tirta Mayang Kota Jambi. Kemudian laporan tersebut dicatat dan dianalisis berdasarkan risikonya untuk kemudian dilakukan eskalasi penyelesaian keluhan pelanggan.

Keluaran dari proses ini berupa laporan penanganan insiden yang telah dekerjakan oleh petugas perbaikan pada bagian Pengaduan dan Pelayanan Gangguan Pelanggan PDAM Tirta Mayang Kota Jambi.

b. Proses Request Fulfillment

Masukan ke dalam proses ini berupa laporan permintaan layanan melalui sms ataupun pelanggan yang datang langsung ke bagian Pengaduan dan Pelayanan Gangguan Pelanggan PDAM Tirta Mayang Kota Jambi. Kemudian laporan tersebut dicatat dan dianalisis berdasarkan urgensinya untuk kemudian dilakukan eskalasi penyelesaian keluhan pelanggan.

Keluaran dari proses ini berupa laporan penanganan permintaan yang telah dekerjakan oleh petugas perbaikan pada bagian Pengaduan dan Pelayanan Gangguan Pelanggan PDAM Tirta Mayang Kota Jambi.

c. Proses Problem Management

Masukan pada proses ini berupa analisis risiko berdasarkan laporan kejadian insiden yang terdapat pada bagian Pengaduan dan Pelayanan Gangguan Pelanggan 
PDAM Tirta Mayang Kota Jambi. Setelah itu akan segera dicatatkan untuk disimpan ke dalam database.

5. Pembuatan Laporan

Pada tahapan pembuatan laporan ini penulis melakukan penelitian sambil menyusun sebuah laporan berdasarkan hasil dari setiap tahapan penelitian yang telah dilakukan.

\section{Hasil dan Pembahasan}

\subsection{GAMBARAN UMUM PDAM TIRTA MAYANG KOTA JAMBI}

Dalam sub bab ini akan dijelaskan mengenai gambaran umum PDAM Tirta Mayang Kota Jambi berdasarkan sumber data.

\subsubsection{Sejarah Perusahaan}

Penyelenggaraan penyediaan air minum perpipaan di Kota Jambi dimulai sejak zaman Pemerintah Hindia Belanda Tahun 1928. Staadfonds atau Pemerintah Kota pada waktu itu mendirikan waterleiding bedrijf, selanjutnya dengan Surat Keputusan Walikota Kepala Daerah Tingkat II Jambi No. 25/X/1974 tanggal 27 Maret 1974 ditetapkan menjadi Perusahaan Daerah Air Minum.

Tahun 1978-1983, proyek Lima Kota membangun sistem penyediaan air minum di Kota Jambi, salah satu kegiatan proyek tersebut membangun IPA Broni, dan membangun IPA Jambi Seberang.

Tahun 1997-1998, Proyek kerjasama/kemitraan PDAM dengan Pihak Swasta mengembangkan sistem penyediaan air minum di Wilayah Barat Kota Jambi khususnya Kecamatan Telanaipura dan Kotabaru dengan membangun IPA Aur Duri dan jaringan pipa induk distribusi.

Tahun 1997-2000, proyek Sumatera Urban Development Sector Project (SUDSP) merehabilitasi dan meningkatkan kapasitas IPA Broni, dan pembangunan Reservoir di Jl. M. Kukuh Kecamatan Kota Baru. Pada tahun 2005, Pembangunan Booster Pump yang berlokasi di Tanjung Pasir Jambi Kota Seberang ditujukan untuk memperbaiki pendistribusian air kepada pelanggan di Kecamatan Danau Teluk dan Kecamatan Pelayangan. Pada tahun 2006, pembangunan pipa induk di Jambi Kota Seberang dan Kotabaru Pada tahun 2007, Pembangunan Reservoir pada lokasi Mayang Mengurai yang dimaksudkan untuk memperbaiki dan memperluas jaringan di Wilayah Kecamatan Kota Baru.

\subsubsection{Visi, Misi dan Tujuan Perusahaan}

Dalam menjalankan kegiatan operasional sehari-hari manajemen PDAM Tirta Mayang Kota Jambi tetap berpegang pada visi, misi dan tujuan perusahaan sebagai berikut:

a. Visi

Terwujudnya Perusahaan pelayanan air minum yang sehat dan handal dengan Sumber Daya Manusia berkualitas dan teknologi yang cerdas (smart technology). 


\section{b. Misi}

a) Memberikan pelayanan air yang berkualitas dan jumlah yang cukup dengan tarif terjangkau (affordable).

b) Meningkatkan derajat kesehatan dan kesejahteraan masyarakat Kota Jambi melalui penyediaan air minum.

c) Memberikan kontribusi Pendapatan Asli Daerah (PAD).

d) Mendukung pertumbuhan dan perkembangan perekonomian daerah.

e) Menjadi agen pembangunan.

\section{c. Tujuan}

Berdasarkan Peraturan Daerah Kotamadya Daerah Tingkat II Jambi Nomor 7 Tahun 1974 tujuan pendirian PDAM Tirta Mayang Kota Jambi yaitu:

a) Melaksanakan Pembangunan Daerah khususnya dan Pembangunan Ekonomi Nasional umumnya.

b) Peningkatan kesejahteraan masyarakat menuju masyarakat adil dan makmur berdasarkan Pancasila.

\subsubsection{Tugas Pokok dan Fungsi Perusahaan}

\section{a. Tugas Pokok}

Menyelenggarakan pengelolaan air minum untuk meningkatkan kesejahteraan masyarakat yang mencakup aspek sosial, kesehatan dan pelayanan umum.

b. Fungsi
a) Fungsi Produksi

i. Mengusahakan pengadaan/penyediaan air minum sesuai dengan Program Pembangunan Pemerintah Kota Jambi

ii. Membangun, mengelola dan memelihara Bangunan Sadap (intake) dan Instalasi Pengolahan Air serta tempat penyimpanan air.

iii. Membantu membangun dan atau memberi bantuan teknis penyediaan air minum melalui pemanfaatan mata air atau sumur dalam (deep well), yang dipergunakan untuk keperluan penduduk.

iv. Mengadakan penelitian laboratoris terhadap sumber dan produk air minum sesuai dengan standar baku mutu kesehatan.

b) Fungsi Distribusi

i. Membangun dan memelihara pipa distribusi induk, pipa retikulasi dan pipa dinas serta fasilitas lainnya.

ii. Mengatur serta mengawasi distribusi dan pemakaian air.

c) Fungsi Penjualan

Menagih uang rekening air dan penghasilan non air lainnya baik yang dilaksanakan sendiri maupun kerjasama dengan pihak ketiga.

d) Fungsi Pelayanan

i. Pengumpulan data untuk proyeksi kebutuhan air dan penjualan serta penyusunan tarif air.

ii. Melayani permintaan langganan air minum dari masyarakat untuk perumahan, perusahaan, hotel, keperluan sosial, dll, dengan pemasangan instalasi dan meter air. 
iii. Mengambil tindakan terhadap adanya pemakaian air yang tidak syah (kerjasama dengan Poltabes Jambi), melakukan tera meter air (kerjasama dengan metrologi), menyegel, dan membongkar instalasi serta meter air.

iv. Menyediakan air dalam rangka membantu memenuhi kebutuhan fasilitas kota seperti untuk penanggulangan bahaya kebakaran, pemeliharaan taman, dan sebagainya.

v. Membantu Pemerintah Kota dalam rangka mengatur, memberikan izin dan mengawasi usaha-usaha instalasi air minum (instalatur) di wilayah Kota Jambi.

vi. Meningkatkan mutu ketrampilan dan kesejahteraan pegawai dalam pengembangan karier untuk meningkatkan produktifitas dan pelayanan umum.

\section{Kesimpulan Dan Saran}

\section{A. Kesimpulan}

Berdasarkan hasil penelitian dan pembahasan yang telah dilakukan, berikut adalah beberapa kesimpulan yang dapat diambil:

1. Rancangan sistem informasi manajemen layanan pelanggan pada PDAM Tirta Mayang Kota Jambi menggunakan framework ITIL versi 3 area service operation.

2. Framework ITIL versi 3 akan terbentuk sistem layanan teknologi infomasi yang lebih sistematis dan terdokumentasi pada PDAM Tirta Mayang Kota Jambi.

3. Sistem informasi manajemen layanan pelanggan pada PDAM Tirta Mayang Kota Jambi dengan framework ITIL versi 3, dapat membantu manajemen PDAM Tirta Mayang Kota Jambi dalam membuat keputusan terkait dengan pengaduan dan pelayanan gangguan.

\section{B. Saran}

Setelah ditarik kesimpulan, adapun saran dari penulis adalah sebagai berikut:

1. Untuk mendapatkan manfaat secara keseluruhan dari sistem informasi manajemen layanan pelanggan pada PDAM Tirta Mayang Kota Jambi ini sangat baik jika mengimplementasikan keseluruhan framework ITIL yang digunakan di dalam metode ITSM.

2. Lingkup penanganan masalah dapat diperluas kebagian layanan non teknis, sehingga pihak manajemen PDAM Tirta Mayang Kota Jambi mendapatkan gambaran secara luas tentang permasalahan yang terjadi.

3. Jika ingin mengembangkan sistem ini akan mengacu pada prototipe yang telah ditetapkan, sehingga pengembangan sistem hanya melanjutkan yang sudah ada, sehingga tidak memulai dari awal yang akan menguras tenaga, waktu dan biaya.

4. Untuk kesempurnaan penelitian ini, sangat diharapkan kepada peneliti selanjutnya agar dapat mengembangkan penelitian ini ke arah yang lebih baik lagi di masa yang akan datang dengan penambahan:

a. Fitur peta lokasi dimana terjadinya gangguan, dengan peta lokasi akan mempermudah mencari titik terjadinya gangguan pelayanan.

b. Dikembangkan ke arah jaringan client server sehingga sistem yang dirancang tidak hanya terfokus pada 1 (Satu) unit pelayanan saja, melainkan juga dapat terhubung ke seluruh cabang PDAM Tirta Mayang Kota Jambi. 


\section{Daftar Rujukan}

1). Alamsyah, Fahrizal; \& Community SmitDev. 2009. e-Business Membangun Bisnis Hosting dan Domain. Jakarta: Elek Media Komputindo.

2). Ali, Hapzi. 2010. Sistem Informasi Manajemen Berbasis Teknologi Informasi. Yogyakarta: Hasta Cipta Mandiri.

3). Cartlidge, Alison; Rudd, Colin; Smith, Marco; Wigzel, Paul; Rance, Stuart; Shaw, Sue; \& Wright, Theresa. 2012. An Introductory Overview of ITIL® 2011. United Kingdom: The Stationery Office.

4). Dennis, Alan; Wixom, B. H; \& Tegarden, David. 2010. System Analysis and Design with UML. United States: WILEY.

5). Fatta, H. A. 2007. Analisis dan Perancangan Sistem Informasi. Yogyakarta: Andi.

6). Fisher, C. A. 2006. Manage Digital Assets with ITIL: Improve Product Configurations and Service Management. Jurnal of Digital Asset Management, Volume 2, Nomor 1, Palgrave Macmillan Ltd. 